\title{
STRATEGI DIVERSIFIKASI DAN KOMITMEN TATAKELOLA PERUSAHAAN BERDASARKAN KINERJA DAN KEBERLANJUTAN PADA PERBANKAN SYARIAH DI KOTA MAKASSAR
}

\author{
La Ode Sumail dan Mappamiring \\ Sekolah Tinggi Ilmu Ekonomi Makassar (STIEM) Bongaya \\ Email: odesumail@yahoo.co.id,iring@ymail.com
}

\begin{abstract}
This study aims to (1) formulate the company's strategy of diversification towards sustainability Islamic banking; (2) reveal the corporate governance of the company keberlajuntan keberlajuntan Islamic banking; (3) describe the role of a diversification strategy to keberlajuntan through the performance of Islamic banking companies; and (4) describe the role of corporate governance on corporate performance keberlajuntan through Islamic banking. This study is a quantitative approach. The sampling technique is done in proportion of 30 leaders of Islamic banking in Makassar. Data was analyzed using generalized structured component analysis (GSCA). Results of the study found that (1) the diversification strategy is not significant to the company keberlajuntan Islamic banking; (2) governance, positive and significant impact on the continuity of Islamic banking companies; (3) the company's performance and a significant positive role in mediating the effects of diversification towards keberlajuntan Islamic banking; and (4) the performance of the company and a significant positive role in mediating the effects of corporate governance on Islamic banking keberlajuntan. Freshness of this study are: (1) using the foundation of Islam that agency theory agency theory perspective mudaraba and (2) indicators of corporate governance is measured through the concept of Sharia.
\end{abstract}

Keywords: financial performance, mudaraba agency theory, Islamic banking

\begin{abstract}
Abstrak: Studi ini bertujuan (1) merumuskan strategi diversifikasi terhadap keberlanjutan perusahaan perbankan Syariah; (2) mengungkap tatakelola perusahaan terhadap keberlajuntan keberlajuntan perusahaan perbankan Syariah; (3) mendeskripsikan peran strategi diversifikasi terhadap keberlajuntan melalui kinerja perusahaan perbankan Syariah; dan (4) mendeskripsikan peran tatakelola perusahaan terhadap keberlajuntan melalui kinerja perusahaan perbankan Syariah. Pendekatan studi ini adalah kuantitatif. Teknik pengambilan sampel dilakukan secara proporsional yaitu 30 para pimpinan perbankan Syariah di Kota Makassar. Analisis data dilakukan dengan generalized structured component analysis (GSCA). Hasil studi ini menemukan bahwa (1) strategi diversifikasi tidak signifikan terhadap keberlajuntan perusahaan perbankan Syariah; (2) tatakelola perusahaan berpengaruh positif dan signifikan terhadap keberlajutan perusahaan perbankan Syariah; (3) kinerja perusahaan berperan positif dan signifikan memediasi pengaruh diversifikasi terhadap keberlajuntan perbankan Syariah; dan (4) kinerja perusahaan berperan positif dan signifikan memediasi pengaruh tatakelola perusahaan terhadap keberlajuntan perbankan Syariah. Keterbaruan studi ini adalah: (1) menggunakan landasan teori keagenan perspektif Islam yakni teori keagenan mudharabah dan (2) indikator tatakelola perusahaan diukur melalui konsep Syariah.
\end{abstract}

Kata Kunci: kinerja keuangan, teori keagenan mudharabah, perbankan syariah 


\section{PENDAHULUAN}

Paradigma pengguna jasa mulai bergeser dari produk jasa konvesional ke produk jasa syariah. Artinya, ada kecenderungan masyarakat menaruh harapan dan percaya pada industri ini. Hal ini terbukti dengan pesatnya industri bisnis perbankan syariah di Indonesia. Betapa tidak, banyak kalangan yang memberikan apresiasi terhadap kemampuan bank syari'ah bertahan dari terpaan likuiditas. (Akmal, 2008). Meskipun perkembangan perbankan syari' ah secara umum cukup pesat, disisi lain kinerja beberapa bank syariah yang melambat pada semester pertama 2014. Kondisi ini memang cukup kontras dengan kinerja industri perbankan syariah nasional tahun-tahun sebelumnya. Pertumbuhan aset perbankan syariah berdasarkan Statistik Perbankan Syariah sampai dengan April 2014 tercatat hanya sebesar 17,5 persen. Ini jauh di bawah rata-rata pertumbuhan sejak 2005- 2013 yang mampu mencapai 36,1 persen per tahun. Laju pertumbuhan tersebut jauh di atas rata-rata pertumbuhan aset perbankan nasional yang hanya sebesar 16,3 persen per tahun. Untuk itulah industri perbankan syariah mendapat julukan sebagai the fastest growing industry (BI, 2014).

Ada kecenderungan bahwa kemampuan alamiah perbankan syariah untuk tumbuh tinggi mulai menurun. Setelah mampu tumbuh mencapai 47,6 persen dan 49,2 persen pada 2010 dan 2011, laju pertumbuhan aset perbankan syariah menurun menjadi 34,1 persen dan 24,2 persen pada 2012 dan 2013. Penurunan kinerja tersebut terus berlanjut pada 2014 hingga di bawah 20 persen. Hal ini akan berakibat pada keberlanjutan perusahaan perbanakan syariah.

Penurunan kinerja perbankan syari'ah akan menimbulkan konflik keagenan antara pemilik dana dan pengelola dana. Dalam teori keagenan konvensional dari Jensen dan Meckling (1976) menyatakan bahwa apabila manajer melakukan keputusan yang berpihak pada investasi yang produktif (NPV positif) maka masalah keagenan (agency problem) antara manajer dan pemilik (principals) tidak akan terjadi. Sebaliknya, jika keputusan manajer melakukan kegiatan inevestasi yang tidak menguntungakan (NPV negatif) maka masalah keagenan akan muncul.

Kelemahan teori keagenan konvensional dari Jensen dan Meckling (1976) belum mempertimbangkan kaidah relasi profit and loss sharing antara pemberi dana (shahibul mal) dan pengusaha (mudharib) yang menggunakan dana tersebut untuk diinvestasikan dalam berbagai investasi produktif (Adnan dan Mukammad, 2007). Studi ini menggunakan teori keagenan yang berbasis syari'ah yaitu teori keagenan Mudharabah. Kekuatan teori keagenan berbasis syari' ah adalah mengedepankan relasi profit and loss sharing antara pemberi dana (shahibul mal) dan pengusaha (mudharib).

Ada beberapa strategi pengembangan ke depan, antara lain: Pertama, mendorong bank unum konvesnsional selaku induk Bank Umum Syari'ah (BUS) maupun Unit Usaha Syari'ah (UUS) yang selama ini kurang melakukan diversifikasi usaha. Keseriusan ini, misalnya, dapat ditunjukan dengan peningkatan permodalan, pemanfaatan jaringan kantor dan jaringan informasi teknologi, dan menempatkan the best employee di bank syari'ah anak usahanya, sehingga mampu berinovasi dalam melahirkan produk dan layanan yang prima, sehingga dapat setara dengan kualitas layanan bank konvensional induknya. Kedua, mengedepankan tatakelola berbasis syari'ah. Misalnya, terus menggalakan program sosialisasi dan edukasi mengenai perbankan dan keuangan syari'ah mengingat masih banyak masyarakat yang belum memahami dan memanfaatkan layanan perbankan 
syari'ah. Diversifikasi dan tatakelola akan mempekuat berlangsungnya aktifitas perusahaan (Lins dan Henri Servaes,1999).

Masih terdapat variasi hasil penelitian dan juga masih terbatasnya penelitian tentang hubungan diversifikasi dengan sustainable perusahaan dan hubungan tatakeloal dengan sustainable perusahaan. Studi Mendonça dan Alexandre Luzzi 2013; Weber et al., 2005 menemukan diversifikasi berpengaruh positif dan signifikan terhadap kebrlanjutan. Strategi diversifikasi dapat mendorong pertumbuhan berkelanjutan, mengrurangi risiko bisnis dan memperkuat pangsa pasar perusahaan (Mendonça dan Alexandre Luzzi 2013). Berbeda dengan studi Shyu dan Yen, 2009 bahwa diversifikasi tidak berpengaruh signifikan bagi perusahaan masih dalam tahap pertumbuhan. Mereka juga menemukan bahwa diversifikasi memiliki hubungan terbalik pada perusahaan dalam tahap matang/dewasa. Karena itu, studi yang terkait diversifikasi dengan keberlanjutan masih terbatas sehingga menjadi peluang penelitian ini.

Studi tentang hubungan diversifikasi dengan keberlanjutan (sustainable) perusahaan masih terbatas. Karena itu, menjadi peluang penelitian ini. Keberlanjutan perusahaan merupakan integrasi dari strategi perusahaan, efektifitas sebagi tujuan jangka panjang perusahaan, kinerja dan daya saing, aspek lingkungan dan social, serta yang lebih terpenting adalah tatakelola perusahaan (Kocmanova et al., 2011). Tatakelola yang baik dapat menyusuikan secara signifikan dengan perubahan eksternal perusahaan, kebijakan dan kondisi politik (Schmitter 2010). Karena itu, perusahaan yang sanggup untuk tetap eksis dan sustainable adaalah perusahaan yang visioner (Kocmanova et al., 2011). Letak pembeda tetap eksis dan berkelnajutan adalah perusahaan yang lebih cenderung memperhatikan intangible asset bukan semata-mata mengejar return. Penelitian tentang hubungan tatakeloala dengan sustainable masih terbatas, sehingga menjadi motivasi penelitian ini.

Hubungan diversifikasi dengan kinerja perusahaan menunjukan hasil postif dan signifikan (Campilo dan Roberto 2010; Daud et al., 2009; Afza et al., 2007; Miller 2006; Villalonga 2004; Palich et al., 1999; Pandya dan Narendar 1998). Berbeda dengan penelitian Kahloul dan Slaheddine (2010); Chakrabarti et al., (2007) menunujukan hasil negatif dan signifikan antara diversifikasi dan kinerja perusahaan. Sedangkan, studi Berger dan Eli Ofek (1995) menemukan bahwa diversifikasi menurunkan nilai perusahaan.

Strategi ini akan memperkuat kinerja dan berdampak pada keberlanjutan bisnis perusahaan. Palich et al., (2000) diversifikasi bisnis adalah keanekaragaman jenis usaha baik yang saling berkaitan (related business) maupun yang tidak saling berkaitan (unrelated business). Sedangkan menurut Campillo dan Roberto (2010); Pandya dan Narendar (1998) diversifikasi merupakan bentuk pengembangan usaha dengan cara memperluas jumlah segmen secara bisnis maupun geografis maupun memperluas market share yang ada atau mengembangkan berbagai produk yang beraneka ragam.

Studi Hussin dan Radiah Othman (2012); .Filatotchev (2005); Campbell dan Phyllis (2002) menemukan bahwa tatakelola perusahaan berpengaruh positif dan signifikan terhadap kinerja. Semakin baik tatakelola perusahaan semakin baik kinerja perusahaan dan berdampak pada nilai perusahaan (Maximiliano Gonzalez, 2008; Chhaochharia dan Yaniv Grinstein, 2007). Penelitian Overheu dan Julie Cotter 2009 menemukan bahwa tatakelola berpengaruh positif dan signifikan terhadap kinerja dan berdampak pada sustainable perusahaan. Sementara, penelitian Aluchna (2009) menemukan bahwa tatakelola berhubungan tidak signifikan dengan kinerja. 
Penelitian (Aggarwal 2013; Ojo 2009; Weber et al., 2005) menemukan bahwa kinerja berpengaruh positif dan signifikan terhadap keberlanjutan. Berdasarkan variasi hasil studi sebelumnya dan keterbatasan dari beberapa hubungan antar variabel, maka ide studi ini adalah mengisi kekosongan penjelasan dan mengisi celah dengan meletakan kinerja perusahaan sebagai variabel mediasi.dengan bersandarkan pada teori keagenan mudharabah.

\section{METODE}

Pendekatan studi ini adalah paradigm kuantitatif. Populasi penelitian ini adalah Bank Umum Syaria'ah (BUS) yang ada di Kota Makssar sebanyak 6 BUS. Sampel penelitian ini adalah para pimpinan perbankan syariah di Kota Makassar sebanyak 30 orang. Teknik penarikan sampel secra proporsional pada masing-masing perbankan Syariah di Kota Makassar (proportionated random sampling). Untuk menguji hubungan antar variabel, alat analisis yang digunakan adalah generalized structured component analysis (GSCA). Menjadi pertimbangan penggunaan alat analisis GSCA adalah sampel dalam jumlah kecil.

1) Diversifikasi merupakan upaya mensinergikan antara bisnis utama dengan bisnis yang baru dari diversifikasi. melalui segmen usaha. Diversikasi diukur dengan menggunakan pendekatan Entropy index (Jacquemin and Berry 1979; Palepu 1985) dengan formula sebagai berikut.

$$
\mathrm{DIV}=\sum_{I=1}^{n} P i \ln \left(\frac{1}{P i}\right)
$$

Dimana, n, adalah jumlah perusahaan di segmen bisnis dan $\mathrm{P} i$ adalah jumlah penjualan di segmen bisnis. Semakin indeks mendekati ke angka satu, maka penjualan perusahaan akan terkonsentrasi pada segmen tertentu.

2) Tatakelola perusahaan perbankan syari'ah merupakan penggunaan prinsip-prinsip syari'ah dari aspek mikro. Indikator pengukuran tatakelola perbankan syari'ah adalah (1) siddiq, (2) tabligh, (3) amanah dan (4) fathanah (Aminudin 2014).

3) Kinerja Keuangan perusahaan merupakan pencapaian laba setelah zakat yang di biayai oleh ekuitas. Rumus yang digunakan sebagai berikut:

$$
\text { ROE }=\frac{\text { Laba Bersih }+ \text { Zakat }}{\text { Total Equitas }}
$$

4) Keberlanjutan (sustainable) merupakan daya hidup perusahaan secara terus menerus. Indikator keberlanjutan mengadopsi ukuran yang digunakan oleh Aggarwal 2013; Angelo A dan Cudia 2011 yakni (1) etika bisnis (2) ekonomi (3) keterlibatan komunitas (4) lingkungan sosial.

\section{HASIL DAN PEMBAHASAN}

Nilai FIT berkisar dari 0 sampai 1. Jadi, model yang terbentuk dapat menjelaskan semua variabel yang ada sebesar 0.519. Keragaman yang dapat dijelaskan oleh model adalah sebesar 51,9\%, walaupun cukup besar di atas $50 \%$ maka model bisa dikatakan cukup baik. 


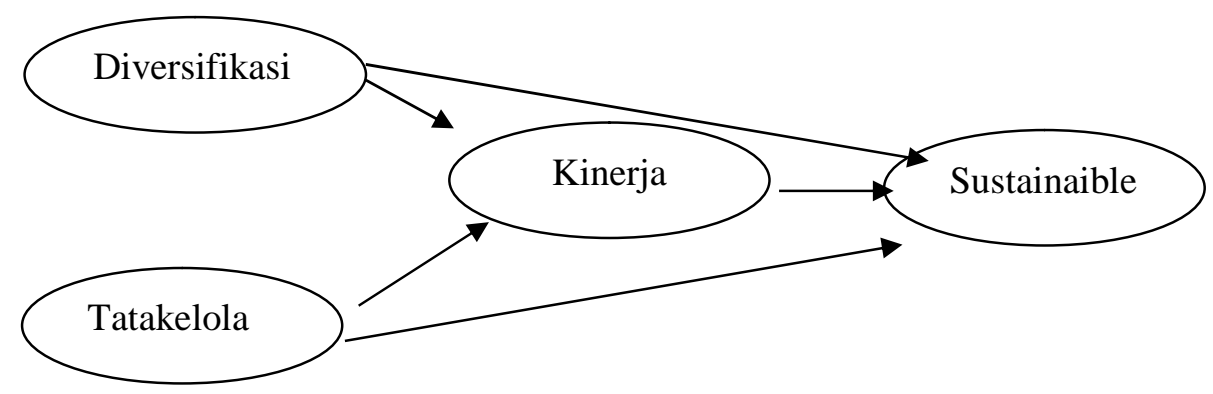

Berdasarkan data empirik yang diajukan dalam studi ini dapat dilakukan pengujian terhadap hipotesis yang diajukan. Tabel 1.1 merupakan pengujian hipotesis dengan melihat nilai estimate dan SE jika lebih kecil dari 0,05 maka hubungan antara variabel signifikan. Hasil pengujian pengaruh langsung (direct effect) disajikan pada Tabel berikut ini:

Tabel 1. Hasil Analisis Koefisien Jalur

\begin{tabular}{|c|c|c|c|c|}
\hline Model & Hubungan Antar Variabel & $\begin{array}{c}\text { Koefisien } \\
\text { Jalur }\end{array}$ & $\begin{array}{c}\mathrm{CR} \\
(\mathrm{Uji} \mathrm{t})\end{array}$ & Keterangan \\
\hline \multirow{5}{*}{$\begin{array}{l}\text { Dengan } \\
\text { Variabel } \\
\text { Mediasi }\end{array}$} & Diversifikasi (X1)-> Kinerja (Y1) & 0.311 & $3.0^{*}$ & Signifikan \\
\hline & Diversifikasi (X1 )-> Sustainable & 0.162 & 1.89 & $\begin{array}{l}\text { Tidak } \\
\text { Signifikan }\end{array}$ \\
\hline & Tatakelola (X2) -> Kinerja (Y1) & 0.234 & $2.35^{*}$ & $\begin{array}{l}\text { Sigminkan } \\
\text { Signifikan }\end{array}$ \\
\hline & Tatakelola (X2) -> Sustainable (Y2) & 0.319 & $2.92^{*}$ & Signifikan \\
\hline & Kinerja (Y1) -> Sustainable (Y2) & 0.446 & 2.30 * & Signifikan \\
\hline $\begin{array}{c}\text { Tanpa } \\
\text { Variabel } \\
\text { Mediasi }\end{array}$ & Tatakelola (X2) $\rightarrow$ Sustainable (Y2) & 0.496 & $3.78^{*}$ & Signifikan \\
\hline
\end{tabular}

Diversifikasi tidak berpengaruh signifikan terhadap sustainable perusahaan perbankan syari,ah di Kota Makassar. Artinya, sustainable tidak ditentukan oleh diversifikasi yang dilakukan oleh perbankan syari,ah. Tampknya, etika bisnis yang merupakan refleksi yang terpenting dalam kompenen keberlanjutan perusahaan pada bisnis perbankan syari'ah sehingga mampu mampu bertahan dari terpaan. Terbukti bahwa keterlibatan masyarakat dan percaya dengan jasa perbankan syari,ah. Selain itu, ditengarai bahwa perusahaan perbankan syariah memiliki daya saing yang kuat dan tetap eksis. Tahan terhadap goncangan yang mempengaruhi kinerjanya.

Perusahaan yang sanggup untuk tetap eksis dan sustainable sebagai sebuah living company adalah perusahaan yang visioner. Karakteristik perusahaan yang sustainable adalah perusahaan yang tidak semata-mata mencari dan mengeruk keuntungan, tetapi yang terpenting cenderung memperhatikan intangible asset baik berupa people dan culture. Karena itu, strategi diversifikasi tidak berarti dalam menentukan sustainable perusahaan perbankan syariah.

Studi ini mendukung penelitian Shyu dan Yen 2009 bahwa diversifikasi tidak berpengaruh signifikan terhadap keberlanjutan perusahaan. Karena itu, penelitian ini 
menolak asumsi teori keagenan mudharabah. Hasil konfirmasi asumsi teori dan konsep dalam penelitian ini berlaku untuk semua perusahaan perbankan, namun bisa ditemukan asumsi-asumsi yang berbeda pada perbankan Syariah di luar Kota Makassar. Penelitian ini tidak mendukung Mendonca dan Alexandre Luzzi 2013 dan studi Weber et al., 2005 yang menyatakan bahwa diversifikasi berpengaruh signifikan terhadap keberlanjutan perusahaan. Perbedaan ini ditengarai oleh ukuran diversifikasi dan ukuran keberlanjutan perusahaan yang digunakan. Selain itu, letak pembeda ditengarai oleh objek studi sehingga temuan studi sebelumnya berbeda dengan studi ini. Karena itu, studi ini tidak mendukung asumsi teori keagenan konvensional dari Jensen dan Meckling (1976), tetapi mendukung asumsi teori keagenan mudharabah. Artinya, perbankan syariah bukan saja berorintasi pada target pemenuhan asset, tetapi dibalik yang lebih terpenting adalah ketrlibatan pengguna jasa dan budaya bisnis yang bernuansa syaria'ah.

Kontrak mudharabah dapat digambarkan sebagai suatu relasi kontraktual antara dua pihak, yang diatur oleh syariah, untuk menggabungkan (tenaga) manusia dan modal dana untuk melaksanakan suatu proyek investasi kerjasama yang beresiko tetapi menguntungkan. Pihak pertama adalah pemberi dana ( rabbul maal/shahibul al-maal) yang menyediakan dana yang dibutuhkan dalam pendirian suatu usaha, bisnis atau jasa yang bertujuan untuk menghasilkan keuntungan. Pihak kedua adalah pengusaha (mudharib) menyediakan modal (tenaga) manusia dan berperan sebagai yang menjalankan usaha. Pengusaha juga bertugas untuk menjalankan hak kontrol atas investasi tersebut. Return positif dari kontrak tersebut menghasilkan keuntungan yang kemudian dibagikan kepada kedua belah pihak berdasarkan kesepakatan nisbah yang telah ditentukan di muka. Hasil negatif (kerugian) yang terjadi dalam proses aktivitas (usaha) yang terjadi secara alamiah ditanggung oleh pemberi dana sebagai pihak tunggal penyedia dana. Kerugian akan ditanggung oleh pengusaha jika mengalami kegagalan dalam menjalankan bisnis tersebut adalah berupa tenaga dan waktu yang telah dicurahkan. Jadi kontrak mudharabah merefleksikan inti dari politik ekonomi Islam, dimana dalam sistem ekonomi Islam, pembagian risiko (kerugian dan keuntungan) merupakan aksioma yang fundamental sehingga disimpulkan sebagai teori keagenan mudharabah. Ada kesan bahwa diversifkasi yang dilakukan perbankan syari;ah di Kota Makassar terkesan mengarah pada motif keagenan (agency view).

Tatakelola perusahaan (good corporate governance) berpengaruh positif dan signifikan tehadap keberlanjutan perusahaan perbankan syari'ah di Kota Makassar. Artinya, semakin baik tatakelola semakin kuat keberlanjutan perusahaan perbankan syari'ah di Kota Makassar. Berdasarkan penelusuran bahwa indikator terpenting dari tatakelola perbankan syari' ah adalah fathanah. Nilai ini memastikan bahwa pengelolaan bank dilakukan secara professional dan kompetitif sehingga menghasilkan keuntungan maksimum dalam tingkat risiko yang ditetapkan oleh bank. Temasuk didalamnya adalah pelayanan yang penuh rasa tanggung jawab (mas'uliyah). Selanjutnya, indicator yang kurang terpenting adalah shiddiq. Nilai ini memastikan bahwa pengelolaan bank syari'ah dilakukan denganmoralitas yang menjujung tinggi nilai kejujuran. Nilai ini mencerminkan bahwa pengeloalaan dana masyarakat akan dilakukan dengan mengedepankan cara-cara yang meragukan (Subhat) terlebih lagi yang bersifat dilarang (haram).

Kenyataannya, penerapan tatakelola bank umum berbeda dengan bank syariah. Lazimnya, indikator tatakelola yang diterapakan pada bank umum adalah menerapkan prinsip-prinsip keterbukaan (transparency), akuntabilitas (accountability), pertanggung jawaban (responsibility), independensi (independency), dan kewajaran (fairness). 
Sementara khususnya dalam perbankan syariah dikenal adanya prinsip-prinsip syariah yang mendukung bagi terlaksananya GCG yakni keharusan bagi subyek hukum termasuk bank untuk menerapkan prinsip siddiq, tabligh, amanah dan fathanah (Aminudin 2014).

Studi ini mendukung studi Kocmanova et al., 2011 dan Schmitter 2009 bahwa semakin baik tatakelola semakin kuat sustainable perusahaan perbankan syari'ah di Kota Makassar. Keberhasilan bisnis adalah pendekatan bisnis yang berfokus pada penciptaan nilai bagi pemegang saham dan mempertimbangkan peluang dan risiko yang terkait dengan keberlanjutan usaha dari aspek ekonomi, social dan lingkungan. Pandangan Schmitter 2010 menyatakan bahwa tatakelola yang baik dapat menyusuikan secara signifikan dengan perubahan eksternal perusahaan, kebijakan dan kondisi politik. Karena itu, tatakelola yang baik mendorong perusahaan menjaga keberlangsungan perusahaan terutama dari aspek financial. Overheu dan Julie Cotter 2009 menekankan bahwa praktik tata kelola perusahaan atau pengungkapan keberlanjutan secara signifikan berhubungan dengan risiko gagal bayar dinilai ketika ukuran perusahaan dikendalikan. Penelitian Kocmanova et al., 2011 dilakukan pada induastri manufaktur di negara Eropa berbeda dengan objek penelitian ini. Karena itu, studi ini memperkuat berlakuknya asumsi teori keagenan mudharabah.

Penelitian ini tidak mendukung penelitian Adam et al., 2010 menyatakan bahwa tatakelola perusahaan tidak berarti jika hanya menciptakan nilai bagi pemegang saham tetapi yang terpenting bagaimana melestarikan lingkungan yang tidak mudah ditiru oleh perusahaan lain. Karena itu, tatakelola perusahaan yang baik adalah bagaimana mendorong perusahaan untuk memperbesar ukuran perusahaan dalam arti kepemilikan asset dan kinerja keuangan. Penelitian Adam et al.,2010 dilakukan pada perusahaan manufaktur di Amerika Serikat.

Kinerja keuangan perusahaan berperan secara positif dan signifikan memediasi ;pengaruh diversifikasi terhadap keberlanjutan perbankan syari'ah di Kota Makassar. Artinya, semakin baik diversifikasi semakin baik kinerja keuangan perusahaan dan akan berdampak pada semakin kuatnya keberlanjutan perusahaan perbankan syari'ah di Kota Makassar. Strategi diversifikasi dapat mendorong inovasi produk simpanan yang menarik nasabah loyal dan kurang sensitif terhadap perubahan suku bunga, sehingga mengurangi perilaku arbitrase. Untuk meningkatkan porsi nasabah loyal. Salah satunya dapat dilakukan dengan meningkatkan segmen deposan ritel/kecil yang memang tidak terlalu sensitive terhadap perbahan suku bunga simpanan. Karena itu perbankan syari'ah juga harus dapat melakukan kemitraan strategi dengan korporasi dan institusi.

Perusahaan melakukan diversifikasi adalah perusahaan tidak hanya menciptakan value bagi stakeholders tetapi juga memerlukan diciptakannya sinergi antara bisnis utama dengan bisnis yang baru dari diversifikasi. Ojo (2009) menyatakan bahwa terdapat empat perspektif motif diversifikasi yang dilakukan oleh perusahaan, yaitu sinergi (synergistic), keuangan (financial), pandangan kekuatan pasar (market power view), dan perspektif keagenan (agency view). Begitu pula perusahaan yang masuk kategori perusahaan sustainable tidak sekedar mengejar asset tangible tetapi lebih cenderung memperhatikan aspek lingkungan dan social atau intangible asset ( people dan culture).

Studi ini mendukung studi Campilo dan Roberto 2010; Daud et al., 2009 bahwa semakin baik diversifikasi semakin baik kinerja keuangan dan akan berdampak pada keberlanjutan perusahaan (Aggarwal 2013; Ojo 2009) pada perbankan syariah di Kota Makassar. Objek studi ini berbeda dengan penelitian Aggarwal 2013; Campilo dan 
Roberto 2010; Ojo 2009; Daud et al., 2009. Karena itu, studi ini mendukung asumsi teori keagenan mudharabah.

Selain studi Campilo dan Roberto 2010, studi ini mendukung pula penelitian Daud et al., 2009; Chakrabarti 2006. Studi Daud et al., 2009 dilakukan pada berbagai perusahaan industry di Malaysia. Daud et al., 2009 menginvestigasi pengaruh perusahaan melakukan diversifikasi dengan perusahaan yang tidak melakukan diversifikasi terhadap kinerja dan risiko perusahaan. Sedangkan, objek studi Chakrabarti 2006 dilakukan pada perusahaan manufaktur di enan Negara Asia Timu (Jepang, Indonesia, Malaysia, Singapura, Korea Selatan, dan Thailand periode 1988-2003. Apabila strategi diversifikasi dilakukan yang tidak berorientasi pada tangible asset maka akan menurunkan kinerja perusahaan (Lang dan Stulz, 1994). Pernyataan Lang dan Stulz 1994 diadarkan hasil riset yang dilakukan pada perusahaan manufaktur. Temuan studi Lang dan Stulz 1994 bahwa diversifikasi berhubungan negatif dan signifikan dengan kinerja perusahaan. Artinya, semakin baik diversifikasi semakin rendah kinerja perusahaan.

Lourenço et al., 2010 menemukan bahwa bahwa kinerja perusahaan berpengaruh positif dan signifikan terhadap sustainable. Artinya, semakin baik kinerja perusahaan semakin kuat sustainable perusahaan. Mereka berpendapat bahwa perusahaan yang sustainable adalah perusahaan yang kinerja keuangannya baik dan memiliki nilai pasar tinggi. Studi Lourenço et al., 2010 pengukuran kinerja keberlanjutan perusahaan menggunakan proksi indeks nilai pasar ekuitas. Peneltian mereka menggunakan perspektif teori resource-based. Objek penelitian Lourenço et al., 2010 dilakukan pada perusahaan utilitas dan keuangan, sementara penelitian ini dilakukan pada perusahaan pebankan syariah. Karena itu, penelitian ini memperkuat asumsi teori keagenan mudharabah

Kinerja keuangan perusahaan berperan secara positif dan signifikan memediasi ;pengaruh tatakelola perusahaan terhadap sustainable perbankan syari'ah di Kota Makassar. Artinya, semakin baik tatakelola perusahaan semakin baik kinerja keuangan perusahaan dan akan berdampak pada semakin kuatnya sustainable perusahaan perbankan syari'ah di Kota Makassar. Penerapan prinsip-prinsip tatakelola perusahaan berbasis syari'ah merupakan wujud pertanggung jawaban bank syariah kepada masyarakat bahwa suatu bank syari'ah dikelola dengan baik dan berkualitas, professional dan hati-hati (prudent) dengan tetap berupaya meningkatkan kinerja keuangan. Misalnya, meningkatkan nilai pemegang saham (shareholder's) tanpa mengabaikan kepentingan stakeholders lainnya. Karakteristik tatakelola perbankan syariah adalah mengedepankan intangible asset dan bukan sekedar mengejar return dan tangible asset saja. Orientasi seperti ini akan memperkuat keberlanjutan perusahaan.

Studi ini mendukung penelitian Hussin dan Radiah Othman (2012); .Filatotchev (2005); Campbell dan Phyllis (2002) menemukan bahwa tatakelola perusahaan berpengaruh positif dan signifikan terhadap kinerja. Semakin baik tatakelola perusahaan semakin baik kinerja perusahaan dan berdampak pada nilai perusahaan (Maximiliano Gonzalez, 2008; Chhaochharia dan Yaniv Grinstein, 2007). Tatakelola yang baik akan meningkatkan kinerja perusahaan dan meningkatkan harga saham (Isshaq et al., 2009 dan Filatotchev,2005). Apabila, nilai perusahaan baik berarti merefleksikan bahwa perusahaan telah dikelolah dengan baik dan berkualitas sehingga secara signifikan akan memperkuat sustainable perusahaan (Weber et al., 2005). Selanjutnya, semakin tinggi kinerja semakin kuat sustainable perusahaan. Hasil penelusuran ditemukan bahwa perbankan syariah di Kota Makassar mengalami pertumbuhan laba. Hal ini merupakan refleksi dari kinerja perusahaan bahwa perusahaan telah dikelola dengan baik dan berkualitas. Perusahaan 
yang baik dan berkualitas adalah perusahaan dapat meningkatkan nilai perusahaan dan cenderung eksis dan berkelanjutan dengan berbasis pada people dan culture (Lee et al., 2011).

Studi ini mendukung studi Isshaq et al., 2009. Temuan mereka dimaknai bahwa semakin baik tatakelola semakin tinggi kinerja perusahaan. Studi dilakukan di Negara Ghana dengan objek penelitian Ghana Stock Exchange Factbook dengan periode pengamatan 2001-2007. Selanjutnya, studi Lee et al., 2008 dilakukan pada perusahaan utilitas dan jasa keuangan dengan jumlah sampel 12.197. Periode pengamatan penelitian Lee et al., 2008 dari periode 1992-2003 serta menggunakna tournament theory oleh Lazear dan Rosen 1981. Karena itu, studi ini mendukung teori keagenan mudharabah.

\section{PENUTUP}

Simpulan. Hasil pembahasan diatas dapat disimpulkan bahwa diversifikasi tidak memiliki keterkaitan dengan keberlanjutan perusahaan perbankan syari,ah di Kota Makassar. Artinya, keberlanjutan perusahaan tidak ditentukan oleh diversifikasi yang dilakukan oleh perbankan syari,ah. Tatakelola perusahaan memiliki keterkaitan dengan keberlanjutan perusahaan perbankan syari' ah. Artinya, semakin baik tatakelola semakin kuat sustainable perusahaan perbankan syari'ah. Kinerja keuangan perusahaan berperan secara signifikan dalam memediasi keterkaitan diversifikasi dengan keberlanjutan perusahaan perbankan syari'ah. Artinya, semakin baik diversifikasi semakin baik kinerja keuangan perusahaan dan akan berdampak pada semakin kuatnya keberlanjutan perusahaan perbankan syari'ah. Kinerja keuangan perusahaan berperan secara signifikan dalam memediasi keterkaitan tatakelola perusahaan terhadap keberlanjutan perusahaan perbankan syari'ah. Artinya, semakin baik tatakelola perusahaan semakin baik kinerja keuangan perusahaan dan akan berdampak pada semakin kuatnya keberlanjutan perusahaan perbankan syari'ah. Hasil konfirmasi studi ini adalah memperkuat berlakunya asumsi teori keagenan mudharab pada perbankan syari,ah di Kota Makassar. Studi kedepan, pengukuran kinerja menggunakan Balanced Scorecard (BSC) perspektif syari'ah.

\section{DAFTAR RUJUKAN}

Afza Talat, Choudhary Slahudin and Mian Sajid Nazi. (2007) “Diversification and Corporate Performance: An Evaluation of Pakistani Firms", South Asian Journal of Management, Vol 15, (3): 1-18.

Aggarwal, Priyanka. (2013) "Impact of Sustainability Performance of Company on its Financial Performance: A Study of Listed Indian Companies", Global Journal of Management and Business Research Finance, Volume 13 Issue 11 Version 1.0: 6170.

Akmal, Huriyatul, (2008) Good Corporate Gavernance dan Manajemen Risiko di Bank Syari'ah, Tesis Pascasarjana UIN Sunan Kalijaga, Yogyakarta.

Aluchna, Maria. (2009) "Does Good Corporate Governance Matter? Best Practice In Poland", Management Research News, Vol. 32 No. 2: 185-198

Aminudin. (2014) "Tata Kelola Perusahaan Yang Baik, Manajemen Risiko Dan Kinerja Keuangan Di Bank Syariah", Jurnal Liquidity, Vol. 3, No. : 44-50 
Angelo A. Cortez, Michael and Cudia, Cynthia P. (2011) "Sustainability And Firm Performance: A Case Study of Japanese Electronics Companies", Ritsumeikan International Affairs Vol.10: 321-340

Berger Va. Philip G., Eli Ofek. (1995) “Diversification's effect on firm value”, Journal of Financial Economics 37: 39-65.

Campbell II. Terry L. and, Phyllis Y. Keys. (2002) "Corporate Governance In South Korea: The Chaebol Experience", Journal of Corporate Finance 8 : 373-391

Campillo, Almudena Martínez and Roberto Fernández-Gago, (2011) Diversification Strategy, CEO Management Style and Firm Performance: an Application of Heckman's Two-stage Method, Qual Quant 45:59-73.

Chakrabarti. Abhirup, Kulwant Singh And Ishtiaq Mahmood. (2007) "Diversification and Performance: Evidence From East Asian Firms". Strategic Management Journal. 28: 101-120.

Jensen, Michael C. and W.H. Meckling. (1976) "Theory of Firm: Theory of Firm Managerial Behavior, Agency Cost and Ownership Structure”. Journal of Financial Economics, Vol 3, (4): 305-360.

Kahloul, Ines and Slaheddine Hallara. (2010) "The Impact of Diversification on Firm Performance and Risk: An Empirical Evidence", International Research Journal of Finance and Economics, Issue 35: 150-162

Kocmanová, Alena., Jiří Hřebícek, Marie Docekalová,. (2011) Corporate Governance and Sustainability, Economics and Management:. 16: 543-550

Lins, Karl and Henri Servaes. (2012) "International Evidence on the Value of Corporate Diversification", The Journal of Finance, Vol LIV, (6): 2215-2239.

Mendonça, Paulo Renato and Alexandre Luzzi Las Casas. (2013) "Diversification as a Sustainable Growth Strategy in the Packaging Market: case study of a Brazilian company, Impacta S/A Indústria e Comércio, RISUS”, Journal on Innovation and Sustainability Vol 4, (2): 61-81.

Miller, D.J.: (2006) Technological Diversity, Related Diversification and Firm Performance. Strateg. Manag. J. 27, 601-619.

Ojo, Olu. (2009) Corporate Diversification and Firm Performance: an Emperical Study Current Economic Crisis. No 9: 39-52

Overheu. Christina James and Julie Cotter. (2009) "Corporate Governance, Sustainability and the Assessment of Default Risk", Asian Journal of Finance \& Accounting, Vol. 1, (1) :34-53.

Palich, Leslie E., Laura B. Cardinal and C. Chet Miller. (2000) "Curvilinearity In The Diversification-Performance Linkage: An Examination Of Over Three Decades Of Research", Strategic Management Journal. 21: 155-174.

Palepu, K.: (1985) Diversification Strategy, Profit Performance and the Entropy Measure. Strateg. Manag. J. 6, 239-255.

Pandya, Anil M. and Narendar V. Rao. (1998) "Diversification And Firm Performance: An Empirical Evaluation”, Journal of Financial and Strategic Decisions, Vol 11 (2): 67-81

Schmitter, Philippe C. (2010) Governance Arrangements For Sustainability: A Regional Perspective, Corporate Governance, Vol. 10 No. 1: 85-96,

Shyu, Jonchi and Yen Luan Chen: (2009) Diversification, Performance, and the Corporate Life Cycle, Emerging Markets Finance \& Trade, ol. 45, No. 6: 57-68 
Weber, Olaf., Thomas Koellner, Dominique Habegger, and Peter Ohnemus. (2005) The Relation Between Sustainability Performance and Financial Performance of Firms, Gesellschaft für Organisation und Entscheidung, 4: 1-19.

Villalonga, B.: (2004) "Diversification Discount or Premium? New Evidence from the Business Information Tracking Series". Jurnal Finance. 59, 475-502. 